\title{
Rough riders in the cradle of civilization: Buffalo Bill's Wild West show in Italy and the challenge of American cultural scarcity at the fin-de-siècle
}

\author{
Alessandra Magrin, University of Strathclyde
}

\begin{abstract}
Comparisons with European culture have often generated feelings of discomfort and anxiety in the United States. Since the age of the Enlightenment, American culture has been associated with a desert or wasteland. This conceptual inclination persisted well into the $19^{\text {th }}$ century - when several American writers picked up on the perceived dearth of culture that the American intellectual landscape offered - until the Gilded Age, when the United States powerfully asserted itself as an economic and industrial power. Cultural affirmation remained, therefore, the last frontier for America to conquer. In this context, the soft power operated by Buffalo Bill Cody's Wild West show in Europe proved to be a tremendous tool for the assertion of American cultural vitality on a worldwide scale. America's ultimate validation, I argue, was established when Cody's show landed in Italy, 'the cradle of western civilization', a stage which exuded a powerful significance in the sphere of culture, and which Cody orchestrated as a symbolic translatio imperii, by picturing himself as a Novel Columbus and America as the vessel of human progress. The resonance of Cody's Italian tours had a regenerating effect on America; witnessing Italian culture in a moment of profound decadence fostered America's collective confidence in its cultural superiority and confirmed its newfangled 'exceptionalism'.
\end{abstract}

\section{Keywords}


Buffalo Bill's Italian tours

transfer of rule

cultural inferiority

early global advertisement

transnational westerns

American cultural imperialism

The ambiguous association between American culture and a tabula rasa - an empty space devoid of the intellectual sophistication of Europe - is long-standing. ${ }^{1}$ As the Abbé Raynal (1713-96) wrote in 1770, America was seemingly incapable of producing 'one good poet, not a skilled mathematician, not a single genius in any art or science' (quoted in Kroes 1996: 11). For decades to come, European reviewers of America intensified the lesson of the French philosophe, by stating that Americans 'have done absolutely nothing for the Sciences, for the Arts, for Literature' (Smith 1820, quoted in Woodward 1992: 47-48) or that 'in no department of art, has any work, drama, novel, poem, painting or musical composition been produced which could justly be placed in the first class' (Lepel Griffin, 1884, quoted in Woodward 1992: 50). This tendency persisted well into the nineteenth century, eventually inducing some American writers, such as James Fenimore Cooper (1798-1851) and Nathaniel Hawthorne (1804-64), to buy into this cultural trope, regretting the 'poverty of materials' that the American intellectual landscape offered (Goodheart 1987: 25). Even when the nation was clearly asserting itself as an economic and industrial power, between the Gilded Age and the beginning of the Progressive Era, America's cultural deficit and its alleged inability to be 
independent of Europe continued to be source of collective apprehension. Public opinion, on both sides of the Atlantic, amplified these beliefs in books and newspaper articles addressing the topic of 'Culture - or lack of it - in America'. 'Is America totally lacking in culture?' asked a New York Times journalist in response to a polemical book by G. Lowes Dickinson (1862-1932), 'Have we no gift of conversation? Are we so busy chasing the elusive dollar that we have no time to cultivate the intellectual side? [...]' (Anon. 1909: 1). For writers, artists, and performers, travelling to Europe remained a mandatory rite of passage towards social validation (Warren 2005: 292). One only needs to recall the examples of Henry James, Thomas Cole, Elihu Vedder and Adelaide Phillipps to understand the impact that their European apprenticeships, and particularly their 'Italian Hours', have had on their careers back home. For the American elites, as well, European culture continued to set the standards on which to model one's own, which inherently reinforced the idea of America as the cultural poor relative of Europe (Warren 2005: 292; also quoted in Stetler 2012: 144). So, as Frederick Jackson Turner proclaimed the closing of the Frontier - the leading cultural agent in the history of the United States, according to Theodore Roosevelt - it became clear that cultural affirmation remained the ultimate frontier for America to conquer. In line with Turner's and Roosevelt's influential ideas, the West was soon elevated to represent the epitome of America (White 1994: 50-51). Reminiscent of Emerson's lesson in The American Scholar on nature as the most significant incentive of the mind, the West was therefore envisioned as the quintessential breeding ground for 'true' and 'authentic' American culture; an 'exceptional realm', detached from Europe's sphere of influence (Slotkin 1981: 609). The West and the Frontier also added an element of 'raw masculinity' to the notion of culture, which was lacking in previous understandings of the term, especially in America. Until the Gilded Age, culture was connected with the idea of femininity, designating leisurely, non-utilitarian activities aimed at personal refinement, which entailed a 'passive' or 'receptive' conduct, as 
'genteel' (Trachtenberg 1982: 143-46). Cultivation was therefore associated with the domestic sphere, the eastern elites and, inexorably, with the Old World. From the 1850's onwards, the onset of cultural narratives exalting the role of the West and the Wilderness altered this assumption, so that Europe's untarnished aura of sophistication gradually began to be perceived as weak and effeminate, not to mention obsolete (Stetler 2012: 146). Let us consider the way in which Theodore Roosevelt urged the 'men of the greatest city of the West' (i.e., Chicago) to adopt the 'doctrine of the strenuous life' against that of 'ignoble ease' (1900: 1), or how he asserted in The Winning of the West, that: 'To succeed in the wilderness, it was necessary to possess not only daring, but also patience and capacity to endure grinding toil' (Roosevelt 1897: 174). Another powerful 'influencer' in this direction was Buffalo Bill Cody, who presented audiences with high-impact allegories of hardy plainsmen engaged in 'civilizing' actions over 'savagery' (Turner 1953: 11). His 1886 show brochure insisted that 'without the rifle ball we of America would not be to-day in possession of a free and united country, and mighty in our strength' (show programme 1886, cited in Lewis 2010: 263). These narratives introduced the notion of a civilization attained by action, exertion and labour, and designated the 'Wild' West as the ideal realm of virility and youth, which opposed the industrialized East, and by extension, therefore, Europe was envisioned as passive, emasculating and decrepit. In this emerging dialectic between 'youthful America' and 'antiquated Europe', it can be argued - borrowing from Edward Said's critical concept of Orientalism - that 'antiquated Europe' served the same purpose of an Orient within American minds. ${ }^{2}$ The rise of an industrial and economic empire fostered America's 'Manifest Destiny' as a progressive nation ready to be projected into the future. This enabled American commentators on Europe to adopt attitudes of patronizing superiority towards those nations (such as Italy) where, for a variety of reasons, industrialization was not as advanced. Yet mechanization, far from reassuring the collective preoccupations of fledgling America, only 
concealed cultural anxieties behind a mask of modernity. This attitude revealed Gilded Age America's true ambitions of a cultural revanche over the Old World; it was only by disparaging the national character of the European 'Other' that Americans could elevate and promote their own (Cosco 2003: 8). Indeed, in what would seem a stark contrast to the ideology of the United States as a forward-looking nation, American society continued to surround itself with images of the Old World, and in particular of 'crumbling' ancient Rome. Beginning with the early republic, and up until the end of the nineteenth century, the use of ancient Roman iconography continued to be flaunted in many spheres of American public life. From emblems on monuments, seals and coins, up to Latin mottoes, quotations and names of public buildings - such as the 'capitol', the 'Senate' chamber, or Universities' 'campus' - the metaphors of ancient Rome enveloped the country, by and large, and quickly started to be incorporated into 'modern' American identity. At the same time, comparisons between the new 'American Empire' and 'Imperial Rome' began to appear in a variety of publications, which often designated Americans as 'the New Romans of the West' (Woodward 1992: 63-77). Yet, despite the West's perfect embodiment of the spirit of American Exceptionalism, Old World references and symbols continued to adorn American society. America was not yet fully at ease with the cultural complex of 'lagging behind' Europe - that - which was at times disparaged for its backwardness, but was still generally regarded as the true 'anvil', where real culture was moulded. Half a century later Henry Nash Smith rightfully situated this as an inherent paradox within Turner's thesis (Smith 1973: 260 and Warren 2005: 297). In this context, Buffalo Bill Cody was capable of responding to the collective longing for an 'all-American culture' with a spectacle which represented 'something at once cultural and natural' - both manly and educational (Warren 2005: 293). Branded as 'America's National Entertainment', Buffalo Bill's Wild West show blended elements of circus, rodeo, and historical re-enactment in an 'action-packed patriotic pageant' 
(Lewis 2003: 239). Cody launched his show at a very particular moment in the history of America, when the anxieties over the perceived loss of the Frontier had already triggered a widespread romancing of a lost Edenic past (Wrobel 1991: 61). Therefore, as well as striking sensitive chords for Americans, Cody's 'exhibition' ultimately contributed to the construction of a national cultural narrative. Yet, due to the ambivalent nature of the show - often associated with popular entertainments such as vaudeville and burlesque - its perceived shortage of cultural value puzzled Americans for years, affecting their sense of cultural selfworth (Kasson 2001: 73 and Warren 2005: 297). ${ }^{3}$ The European version of Cody's Wild West was a great improvement on his earlier frontier melodramas and was crafted to fulfil the much lamented necessity of a 'unique' American performance (Warren 2005: 294). Cody's chief effort, therefore, was to present Europeans with a show about America's recent past which could compete with, and hopefully outdo, their own cultural performances, so as to confirm America's cultural position on a worldwide scale. Italy, of all European countries, I argue, represented the most crucial stage of his overseas tours, in which the fate of the show and of America's cultural authority would be incontrovertibly decided. This study will illustrate the extent to which Cody's Italian expedition marked an important chapter in the history of American cultural imperialism, considering that previous scholarship on Buffalo Bill's shows (Reddin, Warren, Rydell and Kroes) has tended to downplay its prominence.

\section{Buffalo Bill's Wild West show in Italy: Mass entertainment as culture}

While America strived to assert its newfangled culture, Italy, on the other hand, appeared to rest on its laurels. Being often represented as a receptacle for most of the Old World's culture, Italy was still perceived, more than any other place in Europe, as the veritable cradle of western civilization. Yet, even if its contemporary reputation was slowly deteriorating in the United States - due to the simultaneous advent of mass Italian immigration and Social 
Darwinism which consolidated negative images of Italy - its past constantly occupied a picturesque and idealized place in the American collective imagination (Fiorentino 2013: 307 and Bertellini 2010: 47). Indeed, Italy's epic civilization and its continuing status of 'agent of culture' ensured that it would remain a prestigious and coveted destination within the realm of arts. Italian architects and artists had work commissioned in the United States from the beginning of the republic, and singers and performers imported to America the Belcanto, and other Italian theatrical traditions from the second half of the nineteenth century onwards. ${ }^{4}$ Particularly in the area of opera and theatre, Italy was still considered the leading authority and exponent (Wilson 2007: 18). While Cody was drawing crowds in the West with his frontier melodrama and early Wild West shows, other crowds were gathering in the East for performances of the so called grande attore theatre, featuring the Milanese actor, Tommaso Salvini (Wilmeth in Wilmeth and Bigsby 1998: 30). ${ }^{5}$ By virtue of its ancient tradition and the symbolic significance it exuded, Italy represented a dramatic testing ground for Cody's show and, culturally speaking, also for the whole of America. Approval from the elites of such a venerable tradition - which included the Pope, the Italian royal family, and aristocrats such as the Primolis and the house of Caetani-Colonna - would mean Cody's acceptance in the pantheon of all-time greats and indicate that 'America herself had finally arrived at the World stage' (Warren 2005: 293-99). In fact, the pressure to take the show to Italy, and specifically to Rome, was coming from multiple directions, though mostly from within the Englishspeaking world. After 1887, the American press pushed Cody to realize 'the design attributed to him of running the Wild West show within the classic precincts of the Colosseum [sic.] at Rome' (Russell 1960: 337). At the same time, a British newspaper published a comical ode to 'Buffalo Bill in Rome' which exhorted Cody to conquer the eternal city, as he had just done with Britain; pointing out that on that matter he had 'done more than Julius C./ He could not down the Britons!', and that taking his 'stalwart Indians braves/ Down to the Coliseum/ The 
old Romans from their graves/ Will arise to see'em' (Cody-Wetmore 1965: 260). Thus, classical culture was still held in high esteem by Anglo-Saxon societies, even as they harboured the hope that Anglo-Saxon power would now surpass the magnitude of the ancient civilizations (Flint 2009: 229). American public opinion saw no better chance to dwell on the rhetoric of Ancient Rome vs. New Romans, than the occasion of the Wild West show's actual performance in Italy.

The Wild West show visited the country for the first time in 1890, stopping at Naples, Rome, Florence, Bologna, Milan and Verona. The show returned to Italy for a second tour in 1906 - which was re-branded as 'Buffalo Bill's Wild West's and the Congress of Rough Riders of the World' - and performed in 34 towns, from Lombardy down to Latium (Buffalo Bill's Wild West Company: 1906). Cody’s first arrival in the Italian peninsula was riddled with insecurities and conflicting expectations, yet, at the same time, it was filled with awe and trepidation: 'This has been the trip of my life', Cody wrote from Naples to an American acquaintance. Taking 'such a big outfit into strange countries' was considered, in fact, an audacious move on Cody's part, even by his own extravagant standards (Cody 1890). For this reason, few international showmen attracted a similar level of public attention. Even the seasoned entertainer, P. T. Barnum, was paid less notice during his extended London tour that same year. ${ }^{6}$ Cody had all eyes on him and this motivated his crew of publicists to work particularly hard to impress Italian crowds accustomed to grandiose feats of showmanship. Yet, not long into the show's first Italian stay, the spectre of America's dearth of culture returned to trouble Cody and his entourage. According to the Wichita Daily Eagle: 'report comes from Rome that Buffalo Bill was extremely mortified when he discovered the ridicule with which the ignorance of American tourists is regarded at that ancient city' (Anon. 1890a: 7). This realization certainly moved Cody to craft a remarkably heightened image of himself - as a man of culture as well as of courage - and to consistently liaise with the highest personalities of fin de siècle Italy. The 
aura of Buffalo Bill as a 'fine man’ preceded him in every Italian city he visited, relentlessly projected in the media thanks to Nate Salisbury, the show's master of ceremonies, and general manager 'Major' John M. Burke, and backed by the letters of endorsement that Cody requested from personalities such as Generals Philip Sheridan and William T. Sherman, which he incorporated into the show brochure. As a result, Cody's artfully fashioned image impressed the Italians from the start: a Neapolitan newspaper defined him as 'the most elegant of all cowboys who brings to the jaded Europeans $[\ldots]$ the spectacle of civilization against barbarity, of the white race subduing and destroying the copper-skinned one' (Kean 1890: 2). A Roman journalist praised him as a man 'full of energy, of vigour [...] his ways are far from being rough, as his life would make one suppose he had, he is instead courteous and possesses much wit in conversation' (Serrao 1890), similarly in Milan he struck the audiences as 'a strong man, of a manly and proud handsomeness, accustomed to privations and hardships, who mastered the language and customs of the Red Skins, an intrepid hunter, despising the danger and at the same time, true gentleman' (Anon. 1890b). The construction of a gentlemanly profile ensured that his merits, authority, and reputation were rarely questioned in Italy. Indeed, the cultural value of Cody's show was perceived as a genuine and instructive counterpart to the other famous spectacle of that era, Barnum's Circus:

If Colonel Cody is very much appreciated, Barnum, who emulates his advertisement profusely and with profit, has instead nothing in common with him: between Buffalo Bill and Barnum there is the same difference between an authentic Indian and an Indian from Liverpool, between a stuffed buffalo and a wild one. Barnum is a notorious charlatan, Buffalo Bill is an old-school pioneer, he has been a valiant soldier and has actually risked his life hundreds of times, before pretending to risk it in mock fights. (Magolli 1890) 
Cody's mediatic ascendancy propelled him within Italian high society, particularly in Rome. It was precisely by attending prestigious Capitoline salons that he was able to open a lot of the doors which guaranteed the popularity of his show for years to come. At a gala night which had him as the special guest, Cody reassured the hosts that 'we do not intend to present to you tomorrow anything in the nature of a circus performance' (Anon. 1890c). Cody was desperate to impress the upper classes, and he did so by distancing himself and his show from the illrepute which circus enjoyed at the time. The Roman stop of the 1890 tour was undoubtedly the most loaded with drama. Competitions were carefully staged so as to monopolize public attention on Cody's feats and to have the spotlight constantly on the Wild West show. One of these was the match Cody organized between American Cowboys and Italian herdsmen, the so-called butteri, which was conceived to silence rumours that the Wild West's bucking broncos had been 'trained' to act 'wild' (Nasi 2006: 76). Already, in Naples, the local press had publicized that 'Buffalo Bill invites anyone owning an indomitable horse to leave it with him for five minutes, promising to return it... as a lamb' (Anon. 1890d: 2). No one came forward there, but the right opportunity for Cody materialized in Rome. By visiting the salon of Count Giuseppe Primoli - an Italian pioneer of photography and cousin of Prince Jerome Bonaparte - Cody met a great lover of horses, Onorato Caetani, Duke of Sermoneta, and his British wife, Lady Constance Adela Bootle-Wilbraham, who, after attending the first performance of the show in Rome, accepted the challenge. The Caetans were convinced that their Italian horses would have been much harder to conquer than the American broncos, so they invited Cody over for breakfast to discuss the contest's arrangements (Colonna Di Sermoneta 1937: 221). It was agreed that Cody's cowboys would try to tame two of Caetani's horses, which, after a number of failed attempts, they succeeded in doing. The victory of Buffalo Bill's men was promptly echoed in the American press with overtly sensationalistic 
tones: 'Buffalo Bill's cowboys made Rome howl with delight last Tuesday by conquering in five minutes two of the wildest horses to be found in all Europe[...]' (Anon. 1890e: 2). The New York Herald also explained, 'The animals came from the Duke's farmhouse [...] he declared that no cowboy on earth could ride one. The cowboys laughed at the boast [...] Every man, woman, and child expected that two or three men would be killed in the experiment' (Anon. 1890f). Cody made sure to reprint the full version of the latter article in the Wild West show's brochure for the 1893 Chicago Columbian Exposition, along with a letter from the US vice-consul in Rome about the illustrious lineage of the 'great lordly family of the Caetans', and on the 'wildest and most unmanageable' nature of their Cajetan breed of horses (Buffalo Bill's Wild West Company 1893: 29). Cody was intent on exorcizing lingering fears of cultural inferiority by reminding Americans of the esteem with which his show's triumph in the 'Cradle of Civilization' was received. The international press continued to monitor Cody's Roman movements and feats: from sightseeing at the Coliseum, to the tribute to the tomb of King Victor Emmanuel II in the Pantheon, until the closing in full regalia, with a papal audience in the Sistine chapel. ${ }^{7}$ In the mind of Americans, eager to become 'the new Romans of the West', this equated to a virtual conquest of the landmarks of the of the Old Word's civilization. The meeting with Pope Leo XIII magnified Buffalo Bill's epic venture in the Eternal City and, more than anything else, validated his prestige as a showman and cultural ambassador for America. The request for a hearing was aided by Monsignor O'Connell of the American College in Rome and Archbishop Corrigan of New York (Anon. 1890g, also quoted in Moses 1996: 87). The possibility of a private audience was discarded, due to the high number of the members of Cody's crew. The company settled for a public meeting in the Sistine Chapel on the 3rd of March 1890, for the anniversary of the Pope's coronation (Anon. 1890h, cited in D'Arcangeli in D'Arcangeli et al. 2013: 16). L'Unione Liberale, a newspaper from central Italy, provided a detailed chronicle of the event: 
You can imagine the strange and fantastic spectacle that the papal parade offered. In the midst of the colourful costumes of the Indians - who at the sight of the Pope being held up on that golden chair [...] knelt on the ground and raised their arms, shouting from the top of their lungs, as if they were in ecstasy-Leo XIII, stood still for a few moments in the middle of the room to accept gifts, then passed among them blessing them with his fingers [...] revealing a sense of intense curiosity in his eyes. At one point it seemed that the Pope made an effort not to laugh. As the papal procession went along, the Indians stood up again and, always shouting, followed him with their eyes, as if they could not break away from the heavenly vision that was being offered to them. They were all gifted holy medals, rosaries and other relics [...]. (Anon 1890i, cited in D'Arcangeli et al. 2013: 21)

Interestingly, the Italian press has focused primarily on the mutual reactions of the encounter between Leo XIII and the Native American performers, omitting to talk about the conversation between Cody and the Pope, while the press coverage in the English language emphasized that fact instead:

The Pope [...] appeared delighted to see the much-talked-of Buffalo Bill. In an answer to a question on the subject of the vast expenses incurred by the enterprise, col. Cody said: - 'Holy Father, we went to Spain because from that country Christopher Columbus started to discover America. We come 
to Rome to make history, and because it is the most ancient and glorious city in Christendom' (Anon. 1890j)

As these words point out, the meeting between Buffalo Bill, Native performers, and the Pope, evoked parallels with the exploit of Christopher Columbus. This analogy is promptly reaffirmed by Burke in an interview with a correspondent of the New York Herald: 'You see' he said 'the Wild West is fulfilling its mission of civilizing the Red man. From Barcelona, the country whence Columbus embarked to discover America, to Italy, his native land, our warriors and cowboys have been most kindly received by the public' (Anon. 1890k). As will be seen, this powerful trope resurfaced periodically in the turn-of-the-century American press, in appraisals of Cody's show, and in other commentaries about America's rising cultural influence. Cody's publicists spread the false information that Cody was a devout Catholic (Anon. 18901), so as to give him an aura of integrity in the public eye, but the great media coverage about the papal audience led to some scepticism even among the Italian press usually unsuspecting and well disposed towards Buffalo Bill - and to the suggestion that the event had little to do with faith. In an irreverent statement, which would prove to be nothing short of prophetic in the coming century, a reporter from the satirical newspaper Don Chisciotte della Mancia remarked that: '[...] Colonel Cody, the tamer of Indians, proudly entered the Vatican, among the stiffest nobility, and fiercely took his place as a representative of a new and modern power: the advertisement' (De Miranda 1890). The overall appreciation of Cody's show by the Italians was good. Notwithstanding some criticism, related mainly to a misunderstanding in the challenge between the Duke of Sermoneta and Cody, and to the show's intense advertising apparatus which Italians had never before been accustomed to (Anon. 1890m), Italy welcomed the Wild West show as a 'highly interesting' (Salgari 1890 in Salgari and Gallo 1993: 44) and 'worthy to be seen' spectacle (Anon. 1890n). At the same 
time, Cody often heaped praise about Italy in his public speeches and interviews. An article from the Galignani Messenger showed Buffalo Bill as positively impressed:

without exceptions we had a better class of people at Rome than in any other city we have ever visited. The Roman aristocracy, great lovers of horses and sport, especially the ladies, were not deterred even by the heaviest rains from coming day after day and remaining through the whole performance. (Anon. 1890r, also in Reddin 1999: 106)

Cody appeared to be so charmed by Rome that he expressed the will to bring the 'Roman mud' attached to the equipment back to America, as a memento 'of the Eternal City that led the civilization of the world' (Anon. 1890o, also in Reddin 1999: 106). This might be seen as demonstrating that America's fascination for classical culture had affected even Cody, who seemed almost morbidly attached to the antiquity of this country. In actual fact, the dramatic affectation of Cody's words reveal how this was yet another a ruse of the showman Buffalo Bill, always determined to flatter the elites and gain the favour of crowds in order to promote his persona. Carrying 'Roman mud' back to America would have been scant consolation for failing to secure the Coliseum as a venue for his Roman show - possibly the greatest blow to Cody's pride, especially after the gargantuan anticipation that the international media had put on him. ${ }^{8}$ For Cody, this would have meant the crowning achievement in the epic mythmaking of his show: the conqueror of wild Indians crossing the arena where the gladiators tamed wild beasts. For the American public conquering this ancient milestone might have been a major leap forward in the affirmation of their own culture, as customs of the New World reached the hallowed ground of the Old. The American press reported dramatic justifications for this disappointment such as that the amphitheatre was 'too small for this 
modern exhibition' (Anon. 1890p, also quoted in Warren 2005: 300) and that 'his request for it has aroused an indignant protest from the clericals who claim that it is sacrilege to give an exhibition on ground saturated with the blood of Christian martyrs' (Anon. 1890q: 1). The real reason was far less glamorous, and concerned health and safety. The Flavian amphitheatre was in a poor state of preservation and would have been too risky to allow inside its premises large gatherings of people at one time, let alone bulky animals such as horses and buffalos. Cody was forced to settle for the much smaller, but better preserved, Diocletian arena of Verona, without having affixed the star-spangled-banner on a shrine of Western civilization such as the Coliseum. As scholar Ann Fabian has written, Buffalo Bill and his Wild West show 'catered to popular tastes, creating a mass audience for the very materials Turner and his fellow professional historians $[\ldots]$ would have reserved to the literate and educated' (1993: 225). In his major 'mediatic ride' (Pons 2002: 1) through Italy, Cody managed to successfully import the concept, until then virtually unknown to Italians, of mass entertainment as a form of culture in its own right. He laid the basis for the development of the so-called 'popular culture' genre in the bel paese. The proliferation started only a few months after Cody's passage, with the release of the first Italian Dime Novel about Buffalo Bill: Buffalo Bill, il domatore delle pelli rosse/Buffalo Bill, Tamer of the Red-Skins (P. Philippoteaux, 1890, also quoted in Lottini 2012: 196); and carried on with the publication of Emilio Salgari's novels (1862-1911): Il re della Prateria/The King of the Prairie (1896) and La sovrana del Campo d'oro/The Queen of the Golden Field (1905) in which the character of Buffalo Bill plays a crucial role. This proliferation, as Lottini has aptly put it, went on to involve theatre and cinema (Lottini 2012: 198-99), as well as the graphic arts (Gallo and Bonomi 1996: 75). It is no coincidence that the 'western' has been twentieth century Italy's most striking example of popular cultural export. ${ }^{9}$

\section{Regeneration through decadence: The Wild West show and Italian cultural decline}


While American newspapers sang the praise of Colonel W. F. Cody and his Wild West show's success in 'the cradle of civilization', they also found it the right occasion to highlight the discrepancy between Italy's olden days and the current state of affairs of the country. In the perception of many Americans, turn of the twentieth century Italy was considered 'a backward nation that was lying in the ruins of its ancient greatness' (Fiorentino 2010: 35). A convergence of causes underpinned this belief. First, the publication of American-authored novels set in Italy played a significant part in the early construction of a controversial collective imagery of the Italian peninsula. Books like The Bravo by James Fenimore Cooper, The Marble Faun by Nathaniel Hawthorne, William Dean Howells' Venetian Life and Mark Twain's The Innocents Abroad all portrayed Italian cities as decaying and wretched places, and its inhabitants as inherently treacherous and dishonest (Buonomo 1996: 18). Second, American newspapers reported increasingly on the miserable condition of the Italian peasantry (Anon. 1902: 8), while eminent politicians - the cowboy president Theodore Roosevelt to name but one - incorporated elements of pseudo-social sciences in their speeches, in an attempt to put forward the idea that the class of immigrants arriving on American shores was irredeemably unfit for assimilation (Luconi 2011: 5). Such rhetoric of cultural supremacy was aimed at enhancing the confidence of Americans. Still insecure about the position of their culture in the western world, Americans feared that the 'cross-fertilisation of cultures' that mass-migration was bringing about - especially contamination by certain groups of migrants, considered 'inferior' - would endanger their national character (Wilson 2007: 17 and Fiorentino 2013: 311). As part of the context in which the Wild West show was played out, these cultural tropes definitely had the effect of creating bias, especially among the press coverage that followed the Wild West show in Italy, but also in Cody, himself, and in the members of his crew, including the Native performers. Cody, who had publicly flattered the aristocracy, the clergy, and the Italian public opinion on many occasions, 
displayed a very different attitude in his private correspondence and conversations with the English-speaking press on the subject of Italy. In a letter from Rome to James Bailey, a new show associate who had worked with Barnum for decades, Cody wrote in confidence 'these people (the Italians) are so d(amn) crazy wild to see something for nothing, they run all over us. I am going to kiss the first New York policeman I see' (Cody 1906). In an interview with the New York Times, Cody also commented on the nature of the Italians, admitting, 'We like the Italians of the upper classes, who are very polite, but the lower classes are mean and not to be trusted'(Anon. 1890r).Cody then goes on to stress the poverty and ignorance of Italians in the late nineteenth century, eventually comparing their customs with those of the Native Americans: 'the method of building the tombs is the same, the custom of decorating the outside of the habitations with paintings is the same, the cloaks the Italians wear wrapped about closely resemble the blankets of the Indians' (Anon. 1890r). In this bizarre theory, Cody casually created a parallel between the believed 'primitivism' of the Native Americans, with that of the 'decaying' and 'regressive' Italians, orphaned by the demise of their great civilization. ${ }^{10}$ Ironically enough, it appears that even the Native American performers lamented the poverty and dilapidation of Italy, which they deemed 'no place for an Indian':

The old chief (Rocky Bear) was explaining what a dusty old time folks used to have when the Caesars were alive. 'The more I see of other countries the more I like America. The cab drivers here are very bad men. When you give them one piece of money they hold out their hand for more. Everyone holds out their hand for more here. That makes my heart heavy. It is not so in the land where the sun goes to sleep [...] My people, I want you to remember that these men who ask money from us, and the small boys who follow us through the streets and laughs at us will all die like the 
people who used to live here, and their houses will fall down like these you see around you'. (Anon. 1890s)

According to other commentators of the Italian tour, it was not just the poor people who were devious and corrupted in decadent Italy but also the rich. A British newspaper recounted the forgery in Naples of 'four-thousand five francs banknotes', which:

Were passed at the door of his (Cody's) show by well-dressed Neapolitans, indeed the elite of Neapolitan society [...] this implies that some hundreds of the highest class $[\ldots .$.$] lent themselves to a fraud to cheat Buffalo Bill. There must have been a$ combination to swindle, and that among the members of the aristocracy at Naples. The Italian papers did not mention this in a tone of disgust, but rather in one of surprise that Italians should have been able to over-reach a Yankee. (Anon. 1892: 1, original emphasis)

These comments, as Paul Reddin has rightly noted, were often used to contrast 'W.A.S.P' traditions and values of the American West with Italy's 'hoary antiquity' and thus served to glorify America's righteous and progressive national character (Reddin 1999: 106-07). The testimony of Cody and his cast members was fuelled by the master narratives of cultural supremacy which the press fostered, helping Americans to revise the role of Europe as the unique producer of culture and to affirm instead the vitality of their own country through the Wild West show, which now stood out for the first time as an international agent of Americanism. By the time the Wild West show returned to Italy in 1906, the United States 
had begun to fulfil the destiny boisterously foretold by the Louisville Courier-Journal in 1896:

We are no longer a squalid Democracy, secure chiefly by reason of our isolation, a Pariah among the governments of men. We are a Nation - with the biggest kind of $\mathrm{N}$ - a great imperial Republic destined to exercise a controlling influence upon the actions of mankind and to affect the future of the world as the world was never affected, even by the Roman Empire... The struggle of the future will be the survival of the fittest. Why should we not begin to look about how things are going and to cast about for our particular interest and glory? (Healy 1970: 46)

To reflect this change, Cody transformed the format of his Wild West show into an ethnographic exhibition of peoples and armies, meeting the collective longing for exposure to the 'exotic' at world's fairs and tapping onto Italy's inferiority complex concerning its lack of foreign colonies. By 1906, the United States had become a de facto colonial power, while Italy's colonial efforts had had embarrassingly disastrous results. Italy was left with the 'hyena's share' of Europe's 'scramble for Africa', and to make matters worse suffered a series of defeats in the regions the government was trying to secure, of which the most crushing occurred in Dogali (1887) and Adwa (1896) (Choate 2008: 31). Considering that several members of Sonnino's and Giolitti's governments had been diligently attending Cody's 1906 show in Rome, it is likely to think that witnessing America's colonial 'splendour' parading before their eyes in the 'Congress of the Rough Riders of the World', revived the frustrated colonial ambitions of the Italians, which a few years on would culminate in the conquest of Libia (1911) (Anon. 1906: 3). ${ }^{11}$ The switch in the Wild West show's format represented a 
form of celebration of the rhetoric of the 'westward course of empire' on a global scale. In the public opinion, Buffalo Bill was elevated to a symbol of American progress, as this article from the Wichita Daily Eagle perfectly articulates:

What has Buffalo Bill done? He has opened a great school of anthropology, and not only wisdom but royalty had been forced to applaud. Surely his entertainment is the greatest that the world has ever seen, and could it have been possible in the vigorous days of Rome, had this mammoth play been enacted in the neighbourhood of the eternal city, the school boy of all nations would today translate its wonders into his mother tongue. Morse had made the two worlds touch the tips of their finger together. Cody has made the warriors of all nations join hands. [...] Buffalo Bill has taught the knowing world a lesson. It was a bold thing to undertake, but this man from the west did it. There often arises a man who makes the world think, but how few have made the world stare? In the years to come, when Cody had passed away, hundreds of imitators wil larise [sic.] to scramble and to strive for a semblance of his marvelous force, but he cannot be approached, for history has marked him as one of her children. Columbus discovered America. The centuries rolled one upon another and a man from the western plains completed the discoverer's work - brought a band of Indians to Rome. (Anon. 1898: 7)

The grandeur of ancient Rome is employed, once again, as a metaphorical comparison for Cody's accomplishments, and another emblematic figure of Italy's past is invoked: Christopher Columbus. Just as the Genoese navigator had contributed to bring modernity in 
the Old World through the discovery of the New, Cody is represented as a 'novel Columbus', a new bearer of progress coming from America to regenerate the decadent Old World.

From these words it seems clear, therefore, that the transfer of rule that America had advocated for itself, with Buffalo Bill as its cultural ambassador, was now considered completed. This sense of momentous change can only have fortified the confidence of the American people, helping them to tame their long-standing sense of cultural inadequacy in comparison with Europe as they strode enthusiastically into the 'American Century'.

\section{References}

Anon. (1890a), ‘Time Turns Back', Wichita Daily Eagle, 21 February, p. 7.

(1890b), Il secolo, 2-3 April, Cody Italian Scrapbook, McCracken Research Library,

Buffalo Bill Center of the West, MS 006.

(1890c), 'Buffalo Bill in Italy', Galignani Messenger, 14 March, Italian Scrapbook.

(1890d), 'Buffalo ecc. ecc.', Il Piccolo, 30-31 January, p. 2.

(1890e), 'Buffalo Bill's Cowboys', The Meridional, 29 March, p. 2.

_ (1890f), 'Roman Wild Horses Tamed by Cowboys', New York Herald, 5 March, Italian Scrapbook.

(1890g), 'Wild West in Rome', Galignani Messenger, 4 March, Italian Scrapbook. 
(1890h), 'Notizie dal Vaticano', La Nazione, 28 February, p. 2.

(1890i), 'Buffalo Bill in Vaticano', L’Unione Liberale, 5 March, p. 2.

(1890j), 'Wild West in Rome', Galignani Messenger, 4 March, Italian Scrapbook.

(1890k), 'Wild West at the Vatican', New York Herald, 4 March, Italian Scrapbook.

(18901), 'Italy', The American Register in Paris, 15 March, Italian Scrapbook.

(1890m), 'Buffalo Bill', Il Corriere Italiano, 18 March, Italian Scrapbook.

(1890n), 'Buffalo Bill', Il Sole, 4 April, Italian Scrapbook.

(1890o), 'Buffalo Bill in Italy', Galignani Messenger, 14 March, Italian Scrapbook.

(1890p), 'Wild West at the Vatican', New York Herald, 4 March, Italian Scrapbook.

(1890q), 'Buffalo Bill's Latest', Pittsburgh Dispatch, 29 January, p. 1.

(1890r), 'Cowboys in Old Verona', New York Times, 18 May, p. 17.

(1890s), 'Roman Society’, New York Herald, 16 March, Italian Scrapbook. 
(1890t), 'A Twenty Years' View', Johnstown Weekly Democrat, 18 April, p. 4.

(1892), Troubadour Land, 13 February, p. 1.

(1898), 'Time turns back: Buffalo Bill's Mirror of the Old Wild West', Wichita Daily

Eagle, 11 September, p. 7.

(1902), 'Misery in South Italy', New York Times, 11 November, p. 8.

(1906), 'La prima rappresentazione di Buffalo Bill', La Capitale, 23 March, p. 3.

(1909), 'Concerning culture - or lack of it - in America', New York Times, 26

December, p. 1.

Bertellini, G. (2010), Italy in Early American Cinema: Race, Landscape, and the Picturesque, Bloomington: Indiana University Press.

Buffalo Bill's Wild West Company (1893), Buffalo Bill's Wild West's and Congress of Rough Riders of the World, McCracken Research Library, Buffalo Bill Center of the West, MS.327.

(1906), Wild West's Show Tour Route, McCracken Research Library, Buffalo Bill

Center of the West, McCracken Library, MS6.2021.

Buonaccorsi, E. (2011), Tommaso Salvini: Un attore patriota nel teatro italiano dell'Ottocento, Bari: Edizioni di Pagina. 
Buonomo, L. (1996), Backward Glances: Exploring Italy, Reinterpreting America (18311866), Madison: Fairleigh Dickinson University Press.

Choate, M. I. (2008), Emigrant Nation: The Making of Italy Abroad, Cambridge: Harvard University Press.

Cody, W. F. (1890), 'Letter from William Cody to Doctor', Naples, 15 February, McCracken Research Library, Buffalo Bill Center of the West, MS6.0068.

(1906), 'Letter from William Cody to James Bailey’, Rome, 25 March, McCracken Research Library, Buffalo Bill Center of the West, MS6.1B222.

Cody-Wetmore, H. (1965), Last of the Great Scouts, Lincoln: University of Nebraska Press.

Colonna Di Sermoneta, V. (1937), Memorie, Milano: Treves.

Cosco, J. P. (2003), Imagining Italians: The Clash of Romance and Race in American Perceptions, 1880-1910, New York: SUNY Press.

D’Arcangeli, M., Volpe, P. and Gelsomini, S.(2013), Papa Leone XIII \& Buffalo Bill, Carpineto Romano: istituto comprensivo Leone XIII.

Miranda, D. (1890), 'Barnum in Vaticano', Don Chisciotte della Mancia, 4 March, Cody Italian Scrapbooks. 
Fabian, A. (1993), 'History for the masses', in W. Cronon and G. A. Miles (eds), Under an Open Sky: Rethinking America’s Western Past, New York: W.W. Norton, pp. 223-38.

Farrell, J. and Puppa, P. (2006), A History of Italian Theatre, Cambridge: Cambridge University Press.

Fiorentino, D. (2010), Gli Stati Uniti e l'Italia alla fine del XIX secolo, Roma: Gangemi Editore.

(2013), Gli Stati Uniti e il Risorgimento d'Italia: 1848-1901, Roma: Gangemi Editore.

Fisher, A. (2014), Radical Frontiers in the Spaghetti Western: Politics, Violence and Popular Italian Cinema, London: I. B.Tauris.

Flint, K. (2009), The Transatlantic Indian, 1776-1930, Princeton: Princeton University Press.

Francaviglia, R. (2011), Go East, Young Man: Imagining the American West as the Orient, Salt Lake City: Utah State University Press.

Gallo, C. and Bonomi, G. (eds) (1996), Buffalo Bill and Tex Willer: Storie e miti dall'Ovest americano, Verona: Colpo di Fulmine Edizioni.

Goodheart, E. (1987), Pieces of Resistance, Cambridge: Cambridge University Press. 
Healy, D. (1970), US Expansionism: The Imperialist Urge in the 1890s, Madison: University of Wisconsin Press.

Jaffe, I. B. (1989), The Italian Presence in American Art, 1760-1860, New York: Fordham University Press.

Kasson, J. S. (2001), Buffalo Bill's Wild West: Celebrity, Memory, and Popular History, New York: Hill and Wang.

Kean (1890), 'Buffalo Bill's Wild West', Il Paese, 28-29 January, p. 2.

Kollin, S. (2015), Captivating Westerns: The Middle East in the American West, Lincoln: University of Nebraska Press.

Körner, A. (2008), Politics of Culture in Liberal Italy: From Unification to Fascism, London: Routledge.

Kroes, R. (1996), If You've Seen One, You've Seen the Mall: Europeans and American Mass Culture, Champaign: University of Illinois Press.

Levine, L. W. (2009), Highbrow/Lowbrow, Harvard: Harvard University Press.

Lewis, R. M. (2003), From Traveling Show to Vaudeville: Theatrical Spectacle in America, 1830-1910, Baltimore: Johns Hopkins University Press. 
Lottini, I. (2012), 'When Buffalo Bill crossed the ocean: Native American scenes in early twentieth century European culture', European Journal of American Culture, 31:3, pp. 187203.

Luconi, S. (2011), ' La rappresentazione degli italiani nell'immaginario statunitense', Diacronie, 5:1, http://www.studistorici.com/2011/01/29/luconi_numero_5/. Accessed 1 October 2016.

Magolli (1890), La Riforma, 20 February, Italian Scrapbook.

Moses, L. G. (1996), Wild West Shows and the Images of American Indians, 1883-1933, Albuquerque: University of New Mexico Press.

Nasi, M. (2006), I Butteri di Cisterna e dell'Agro Pontino, Roma:Palombi.

Philippoteaux, P. (1890), Buffalo Bill: Il domatore delle pelli rosse : Terribili avventure fra $i$ selvaggi indiani, Roma : E. Perino.

Pons, C. M. (2002), 'La chevauchée médiatique de Buffalo Bill', Belphégor: Littérature Populaire et Culture Médiatique, 1:2, http://hdl.handle.net/10222/47657. Accessed 3 October 2016.

Reddin, P. (1999), Wild West Shows, Champaign: University of Illinois Press. 
Roosevelt, T. (1897), The Winning of the West: Volume 1, New York: G.P. Putnam's Sons. (1900), The Strenuous Life: Essays and Addresses, New York: Century.

Russell, D. (1960), The Lives and Legends of Buffalo Bill, Norman: University of Oklahoma Press.

Rydell, R. W. and Kroes, R. (2005), Buffalo Bill in Bologna: The Americanization of the World, 1869-1922, Chicago: University of Chicago Press.

Said, E. W. (1977), Orientalism, London: Penguin.

Salgari, E. and Gallo, C. (ed.) (1993), Arriva Buffalo Bill!, Verona: Edizioni Perosini.

Serrao (1890), 'Intervista con Buffalo Bill', Il Carro Di Tespi ,15-16 February, Italian Scrapbook.

Slotkin, R. (1981), 'Nostalgia and progress: Theodore Roosevelt's myth of the frontier', American Quarterly, 33:5, pp. 608-37.

Smith, H. N. (1973), Virgin Land: The American West as Symbol and Myth, Harvard: Harvard University Press.

Trachtenberg, A. (1982), The Incorporation of America: Culture and Society in the Gilded Age, New York: Hill and Wang. 
Turner, F. J. (1953), The Frontier in American History, New York: Henry Holt and Company.

Stetler, J. S. (2012), ‘Buffalo Bill's Wild West in Germany. A transnational history’, Ph.D. theses, Las Vegas: University of Nevada, http://digitalscholarship.unlv.edu/cgi/viewcontent.cgi? article $=2635 \&$ context $=$ thesesdissertatio ns. Accessed 7 October 2016.

Woodward, C. Vann (1992), The Old World's New World, Oxford: Oxford University Press.

Warren, L. S. (2005), Buffalo Bill's America, New York: Random House.

White, R. (1994), 'Frederick Jackson Turner and Buffalo Bill', in R. White and P. N. Limerick (eds), The Frontier in American Culture, Berkeley: University of California Press, pp. 6-65.

Wilmeth, D. B. and Bigsby, C. (1998), The Cambridge History of American Theatre, Cambridge: Cambridge University Press.

Wilson, A. (2007), The Puccini Problem, Cambridge: Cambridge University Press.

Wrobel, D. M. (1991), 'The closing gates of democracy: Frontier anxiety before the official end of the frontier', American Studies, 32:1, pp. 49-66.

\section{Contributor details}


Alessandra Magrin is a Ph.D. Candidate at the University of Strathclyde, Glasgow, and an associate editor of 'The Papers of William F. Cody', a research project led by the Buffalo Bill Center of the West, Cody (WI). She has published chapters in edited collections and presented papers on travel writing, transnational receptions of Buffalo Bill's Wild West's, and Italian adaptations of the western genre.

\section{Contact:}

University of Strathclyde, School of Humanities and Social Sciences, 141 St James Road, Glasgow, G4 0LT, UK.

E-mail: alessandra.magrin@strath.ac.uk

Notes

\footnotetext{
${ }^{1}$ I wish to thank the Eccles Centre for American Studies for their support at the British Library, where part of this research was carried out, Dr Mark Ellis for his mentorship during the drafting of this work, and the Buffalo Bill Center of the West for their invaluable assistance.

${ }^{2}$ See Said (1977). For adaptations of this concept to the American context see Francaviglia (2011) and Kollin (2015).

${ }^{3}$ About the cultural value of live shows and cultural hierarchy in America, see Levine (1988). ${ }^{4}$ Luigi Persico (1791-1860) realized sculptures for the Capitol, in particular the Discovery of America, representing Christopher Columbus holding a globe with a Native American woman at his side, while Constantino Brumidi (1805-80) painted the celebrated fresco The Apotheosis of Washington in the Capitol's rotunda. For more information on Italian Neoclassical art in America, see Jaffe (1989).
} 
${ }^{5}$ The term grande attore theatre designates the Italian theatrical production of the second half of the nineteenth century. The plays focused primarily on the performance of the actors, and less on costumes and scenic design, therefore the talent of the performers was essential. Tommaso Salvini (1829-1915), gained enormous success in the United States beginning from 1873 and throughout the 1880 's. His popularity grew such that, in 1890 , the Johnstown Weekly Democrat designated him as one of the 'five men who have been prominent through two decades', just ahead of William F. Cody (Anon. 1890t: 4). For more information on Salvini's American career, see Buonaccorsi (2011); for a deeper understanding of the grande attore theatre, see Farrell and Puppa (2006).

${ }^{6}$ Barnum's 1889-90 winter season in London was indeed rather unsuccessful. In the aforementioned letter, Cody shows undisguised mockery: 'I guess Barnum is sorry he followed the Wild West across the Atlantic, I see he closes in London today. I guess he wishes he had closed two months ago-I open in London in May' (Cody 1890).

${ }^{7}$ Major international newspapers talked about Buffalo Bill's Roman stay and in particular about his papal audience: from the French Le Figaro, to the Dutch Het Nieuws van den Dag, and from the Canadian Daily Colonist, to the Australian Brisbane Courier (D'Arcangeli 2013: 66).

${ }^{8}$ His attempt to secure the Coliseum was discussed even in New Zealand's The Press (25 March 1890) and Evening Post (5 April 1890) (D’Arcangeli 2013: 34-35).

${ }^{9}$ For an extended discussion of Italian filmic appropriations of the western, see Fisher (2014).

${ }^{10}$ This rhetoric drew cues from the racial theories of criminal anthropologist Cesare Lombroso, which were starting to gain a reception in America (Bertellini 2010: 72). 
${ }^{11}$ Sydney Sonnino (1848-1922) and Giovanni Giolitti (1842-1928) were two prime ministers of turn of the twentieth century Italy, heavily involved in the 'Scramble for Africa'. For a deeper insight into their politics see Körner (2008). 